\title{
Thoughts on Intellectual and Institutional Links Between African and Black Studies
}

\author{
Godwin Rapando Murunga*
}

\begin{abstract}
Black identity and nationalism in the civil rights era were forged through transAtlantic and Pan-African solidarity. Both African and African-American intellectuals and institutions played key roles in Pan-African nationalism and the sustenance of civil rights struggles across the Atlantic. However, in the 1970s onwards, these Pan-African links were subverted by vertical dialogues between western, especially white, 'experts' of Africa and Africans; a dialogue that was skewed in favour of Africanist paradigms and knowledge because of the obvious unequal distribution of intellectual resources in favour of white researchers in the global North. This shift was also matched by the preponderance of negative themes about Africa, an increasing amount of ignorance in the west of the realities in Africa and the treatment of Africa as a mere object of curiosity and theory testing. This paper locates the growing 'ignorance' of African realities among African-Americans in the rise and dominance of Africanist Africa, its disengagement from Black Studies, the marginalisation of African-American and African scholarship (conducted by black scholars) in Euro-American scholarship and the de-emphasis of radical and Black intellectual traditions in the mainstream study of Africans. The paper proposes the enhancement of direct horizontal dialogue between Africans and African-Americans instead of the vertical dialogue between Africans and Africanists which has failed to provide an objective presentation of Africa's achievements and failures, gains and losses.
\end{abstract}

\section{Résumé}

L’identité noire et le nationalisme dans la période des droits civils ont été forgés à travers la solidarité transatlantique et panafricaine. Les intellectuels et les institutions africaines et afro-américains ont joué un rôle clé dans le nationalisme panafricain et dans le renforcement des luttes pour les droits civils à travers

* Kenyatta University, Nairobi, Kenya. 
l'Atlantique. Toutefois, à partir des années 1970, ces liens panafricains ont été subvertis par le dialogue vertical entre des «experts» occidentaux, en particulier des blancs, de l'Afrique, et les Africains. Ce dialogue a été faussé au profit de paradigmes et de connaissances africanistes du fait de l'évidente distribution inégale des ressources intellectuelles en faveur des chercheurs blancs au Nord. Ce changement a également été jumelé à la prépondérance des thèmes négatifs sur l'Afrique, une ignorance croissante en Occident des réalités de l'Afrique aussi bien qu'au traitement de l'Afrique comme un simple objet de curiosité et de test théorique. Cet article situe l'«ignorance » croissante des réalités africaines chez les Afro-américains dans le contexte de la montée et la dominance de l'Afrique africaniste, leur désengagement par rapport aux Etudes Noires, la marginalisation des recherches afro-américaines et africaines (menée par des chercheurs noirs) dans la production de connaissance euro-américaines et la désaccentuation, dans les principales études des Africains, des traditions intellectuelles radicales et noires. Cet article propose le renforcement du dialogue direct et horizontal entre les Africains et les Afro-américains en lieu et place du dialogue vertical entre les Africains et les africanistes qui n'a pas réussi à fournir une présentation objective des réalisations et des échecs, des gains et des pertes de l'Afrique.

If a race has no history, if it has no worthwhile tradition, it becomes a negligible factor in the thought of the world, and it stands in danger of being exterminated (Carter G. Woodson).

\section{Introduction}

The story of the black diaspora began in Africa during the slave trade era or before. ${ }^{1}$ Since then, black people, irrespective of their location, have been brutalised and humiliated through the experience of enslavement, colonialism and neo-colonialism. In all these, skin colour has determined how black people are treated. Skin colour is not just about race. Recent scholarship has been content to dismiss race as a mere biological myth and to throw it to the dark alleys of another so-called meaningless category (Gilroy 1993). Race is not simply an invented category. Of immediate concern is an accumulated heritage of hate loaded onto black people in the world who have alternately been treated as uncivilised, primitive, inferior, traditional and thus less than human. It is such attitudes and the hate they spawned that explain the brutalisation and humiliation of black people on plantations in the Caribbean, in segregated ghettos in the US, and in colonial workplaces in Africa. The attitudes and the hate they spawn are real. They grow from racism. Race may be a social construction suspended above reality, but racism is not. Racism identifies and links black folk into a disempowered group though it has also inadvertently united the black race as a viable community capable of 
resisting white supremacy. Given this, does it matter whether one is located on the continent or in the diaspora?

The solidarity of black people in the world is not well assured and it therefore matters whether one is within Africa or not. We live in a world where black people exist in mutual 'ignorance' of one another, of their collective experiences before and after the raptures of slavery, of their changing cultures, values and lifestyles in different regions of the globe and of the urgent need for a collective struggle towards emancipation against white supremacy. This ignorance is as much from the African side as it is from the diaspora. It is still common to find some African-American students whose knowledge of basic African geography is very poor. Alternatively, it is also common to hear visiting Africans accuse African-Americans of being lazy and noisy. These may be isolated examples and do not prove the rule. But sometimes, the rule does not have to be proved. More important is that they illustrate that the ideas of Africans and Africa-Americans about each other are tainted by mutual ignorance, suspicion and stereotypes. ${ }^{2}$

This article focuses on the role of African Studies in the US (and its British antecedent) in fostering ignorance about Africa in the US and in alienating black people from each other. Although we are aware of many other explanations for the growing ignorance between black people across the Atlantic, we isolate African Studies because of its role in knowledge production. The study will locate the growing ignorance of African realities in the rise and dominance of Africanist Africa, its disengagement from Black Studies, the marginalisation of African-American and African scholarship (conducted by black scholars) in American scholarship and the de-emphasis of radical and black intellectual traditions in the mainstream study of Africa. Africanist Africa is defined as a body of knowledge about Africa produced, dominated and transmitted by largely white scholars (plus a small cohort of conservative black intellectuals) who have assumed the expert status on Africa. Their knowledge emphasises a warped image of Africa often refracted through the modernisation gaze. It perceives and explains African experiences by analogy, emphasising what Africa ought to be, not what it actually is. This knowledge is Afro-pessimist in orientation, and is more concerned to serve Euro-American foreign policy interests in Africa than the welfare of and social struggles waged by Africans against the abuses of the neo-colonialism and a local comprador ruling class. Given these, the paper observes that African-American image of Africa is fed more by this warped presentation than by the realities on the continent. This presentation has not just fostered ignorance, it has accelerated the decline of Pan-African solidarity. As a consequence, the most affected are the younger generation whose 
contacts across the Atlantic are forged through the media or Africanist knowledge. The article proposes enhancement of direct horizontal dialogue between African and African-Americans as a remedy instead of the vertical dialogue between Africans and Africanists that has so far failed to present Africa's achievements and failures, gains and losses.

\section{African Studies and the Rise of Africanist Africa}

The African Studies industry in the United States is a child of the American empire. It developed to meet the needs of ever-expanding US corporate and governmental penetration of Africa. This industry is managed by an extended family of interconnected and incestuous 'experts', who, while living off Africa, serve a system pitted against Africa's needs. They are American social scientists, comfortably ensconced in the institutional architecture of the American intellectual environment. Nurtured by foundation and government grants, they operate under the cover of a false neutrality of academic scholarship, which permits them to camouflage their ideological biases and the strategic policy implications of their work (Africa Research Group 1970). ${ }^{3}$

This section makes the argument that African Studies as it is practised in the mainstream US schools has little to do with Africa. Thus, it cannot sufficiently inform its audience about the concrete realities and social struggles of a majority of African peoples. Rather, African Studies is about US foreign interests, interests whose continuing significance were recently emphasised in the debates on funding area studies programmes in the context of the war on terror. Africa is a mere site where these interests are played out. The argument derives from the fact that despite the resources on Africa in the US, the US public is perhaps the most ignorant about Africa (Zeleza 1997). One can attribute this ignorance to the way Americans think about their place in the world. But still, the image African Studies presents about Africa in the US promotes extant imperial stereotypes. Since it dominates as a source of information and knowledge about Africa, the ignorance about the lived experiences in Africa persists. This avenue of information on Africa is backed up by journalistic accounts, accounts that are always done in a hurry and that contrive an equally flawed picture of Africa. Since US foreign interests in Africa have most of the time been imperial, it is no wonder that imperialism is a neglected topic in most African Studies discussions. If it is discussed at all, the postmodernised variant is preferred.

Since inception, African Studies have gone through three defining phases: the colonial era up to 1945, the Cold War era up to the mid-1990s, and the post-Cold War era. These phases are basically framed around Euro-American foreign interests in, and imperial relations with, Africa. Nevertheless, 
and in spite of protestations by a few radical Africanists, these interests and relations have defined and determined the canon and content of African Studies. The canon and content have little to do with the welfare of Africans or with local struggles for social justice. They have more to do with what Maxwell Owusu described as 'knowledge as the basis of enlightened policies' (Owusu 1971: 24). This was true of colonial anthropology as it is of African Studies today. It is therefore not far-fetched to argue that African Studies has played a role in creating or perpetuating an 'Orientalised' image of the African people that dominates the Northern perception of other people (Mafeje 1996, Mudimbe 1988).

In the colonial era, African Studies was driven by European imperial interests. Imperialism defined the canon and content of African Studies. The aim at the time was to generate knowledge that made colonial control of Africans easier, knowledge that made what was strange in Africa less so to incoming Europeans. The study of Africa was based in Europe. From their bases in Britain, France, Germany and Belgium, researchers departed to conduct fieldwork in Africa and returned having cannibalised the continent's stores of knowledge. They focused on African languages and customs, their values and cultures but gave their analysis a modernisation slant. In Britain, the study of Africa was institutionalised in 1917 or thereabout when the School of Oriental Studies at the University of London became the School of Oriental and African Studies. This association with orientalism à la Edward Said is instructive. Its stated mission was to train colonial administrators. With bases in Europe dominated by Europeans, African Studies was doubly disconnected from Africa. First, this was a European (not African) study of Africa. Second, there was the distance between the field/object of study and the institutional sites for the study of Africa. Like their current American counterparts, Europeans lacked constant and direct connection to the everyday lived realities in Africa [the significance of everyday lived realities is underscored in Anyidoho's article in this issue].

In the colonial era, the study of Africa was confined largely to the discipline of anthropology (Mafeje 1996). This anthropological emphasis implied that pre-colonial African societies were static and unchanging. The emphasis also supported a particular ideological basis of colonialism. Remember that colonialism was built around two related assumptions. The first was that Africa had no history. The second was that Africans were primitive. Both assumptions served colonial purposes. In the European imagination, societies evolved from simple, largely subsistence modes to complex, largely industrial modes of living. In colonial parlance, the former were traditional and primitive, the latter modern and civilised. Primitive societies were 
unchanging and ahistorical. Civilised societies were dynamic and historical. While primitive societies were left to ahistorical anthropology, the civilised societies were the subjects of history. Since societies followed a linear evolutionary logic from primitive to civilised, from ahistorical to historical, or from traditional to modern, colonialism, it was argued, was the only available engine of progress. ${ }^{4}$ This way, the idea that Africa was ahistorical fed into the ideological justification of colonialism. In colonial Africa, there was only the history of Europeans in Africa, the rest being darkness, which, as Trevor-Roper said, is not a subject of history. By colonising Africa, Europeans brought civilisation to Africa's backwardness.

Africa's backwardness has never been a self-evident fact. Indeed, Africa's backwardness is a European construction, imagined into existence through the literature of travellers, explorers and missionaries. These were the men who imagined and invented the idea of Africa as the heart of darkness; a static, dark, primitive, violent and cannibalistic continent. Rudyard Kipling referred to this backwardness as the 'white man's burden'. Like missionaries and explorers before him, he implored whites of goodwill to conquer the continent and inaugurate civility. The genealogy of the notion of the 'dark continent' and its timing shows its association with the development of imperial thought. 'Africa', according to Brantlinger (1989: 166), 'grew "dark" as Victorian explorers, missionaries, and scientists flooded it with light', and 'the light was refracted through an imperialist ideology that urged the abolition of "savage customs" in the name of civilization'. The notion was also useful in justifying the inhuman and brutal treatment of Africans during slavery and colonialism. It normalised inhumanity and engrained in slavers and colonisers a racist attitude.

The missionaries, explorers and traders who constructed the image of darkness are often eulogised as amateur anthropologists. Their writings are the archetype for colonial anthropology. Their works celebrated the virtues of colonialism as a civilising mission. When colonial anthropology was institutionalised, it retained the shackles of imperialism. It defined its role in relation to the civilising mission, accepting its place as the handmaiden of colonialism (Gough 1967; Mafeje 1996). It accepted and used, with reference to Africa, categories of primitive, barbaric, savage, heathen, pagan, and traditional. Africans were not just primitive, they were inferior and less human than Europeans. They were subjects, a term that evokes a relational link to masters. Thus, the Africans of the colonial anthropologists experience were not the experience of historical being it was the experience of 'Others', of natives. Colonialism institutionalised Europe as the reference point on the 
basis of which Africa's difference was understood. Did the post-colonial era decolonise the idea of Africa as a pre-historic copy of Europe?

The start of the Cold War ushered in new interests and strategies that redefined the study of Africa but it did not decolonise the idea of Africa. The US and Soviet Union ascended as the new superpowers, although the US retained the Anglo-Saxon heritage in the study of Africa. This ascendance came with the realisation that America lacked adequate knowledge about the rest of the world for its super power status. Area studies centres were therefore established or funded in American universities to supply the requisite knowledge for the control of the world. The African Studies Association of the US was founded with a mandate to inform US policy making with the likes of Melville Herskovits writing directly to the CIA to offer support of whichever kind the CIA would require. As an area, Africa was of special interest. This is how African Studies as we know it today in the US came into being. In particular, the new and contending superpowers had strategic interests to protect. To do this, they had to equip themselves with information in aid of their foreign policy.

During the colonial era, the study of Africa was meant to equip colonial powers to be better able to control Africa. In the Cold War, African Studies served neo-colonial powers in the same way. As such, the study was less about the welfare of African people on the continent and its diaspora. It was about American interests and its need to checkmate its Cold War adversaries. This arrangement perpetuated Northern, especially white, dominance in the study of Africa at the expense of a rich black intellectual tradition already developed in Historically Black Colleges and Universities (HBCUs); it entrenched Africanist rather than African perspectives on Africa. In marginalising the role of African-Americans in the study of Africa, African Studies intensified white dominance and control of institutions and resources for the study of Africa. In the process, it disengaged from Black Studies, thereby dealing a blow to existing ideas of pan-African unity.

Although Cold War African Studies appreciated the historicity of the continent, Africa was compartmentalised and taught in area studies. Africa was implicitly conceptualised as different from the rest of the human experience and could not, therefore, be located in mainstream disciplines like history, sociology, political science, etc., that studied mainstream societies. It had separate centres, institutes or programmes of African Studies. These programmes/centres of African Studies are institutionally separate from disciplines. As a result, there are in most American universities departments of history, political science, anthropology, economics and sociology that are separate from programmes of African, Asian, or Middle Eastern studies. 
Disciplines teach human (largely white) experiences while these programmes teach the experiences of 'others'. While disciplines teach the European/ American experiences as human experiences, programmes emphasise the African experiences as native/ethnic experiences (Mamdani 1998). Like colonial anthropology, programmes and centres, by the mere fact of their institutional separateness, emphasise Africa's or Asia's difference from the Euro-American experience. Consequently, this arrangement has established the 'mainstream' white experience as the norm from which others deviate (Liu 1991: 266).

Also, African Studies in the Cold War era took American racial experience as its point of reference and 'continues to operate within certain parameters set out by American racism' (Amory 1997: 102-3). It reproduced within African Studies the racial politics and attitudes within America. For one, American perceptions of Africa have a lot to do with white American racial attitudes towards African-Americans. The marginality of African-Americans in America in part accounts for the disciplinary marginalisation of Africa as an area. This imagination of difference had been at the heart of the creation and settlement of Liberia and Sierra Leone where white proponents of the 'back to Africa' movement based their support on the view that blacks could not be trusted to live amicably with whites. The establishment of area studies programmes had a similar apartheid logic of creating separate spaces for non-whites and this logic was based on the assumption that what was good for African-Americans was good for Africans. However, this logic homogenises all Africans on the basis of race and silences their diversity.

Area studies in the Cold War era also intensified the whiting of African Studies. ${ }^{5}$ Prior to this era, blacks at HBCUs and within black communities had dominated the study of Africa. The work of Martin Delany, W. E. B. Du Bois, Edward Blyden, Leo Hansberry, Ralph Bunche, Alain Locke (the first Black Rhodes Scholar) and Carter G. Woodson stands out in this regard. ${ }^{6}$ Woodson founded the Association for the Study of Negro Life and History in 1915 and the Journal of Negro Studies in 1916. Scholars in Du Bois and Woodson's tradition distinguished themselves by comprehensive analysis of Africa aimed at generating knowledge for the dignity and welfare of black people. For this, they were dismissed as subjective race men whose work was perceived 'as polemical, exaggerated, or merely interpretative' (Robinson 2003: 8). But these scholars were transcontinental in approach and emphasised the unity of Africans.

These scholars also recognised that African American history was inextricably linked to African history. 'African American political discourse at the time [in the 1930s] was keenly informed by and deeply responsive to events 
in Africa, in the Caribbean, and throughout the colonized world' (Von Eschen 1997: 7). ${ }^{7}$ They did not draw distinctions between Africa and its diaspora in the manner in which these are drawn today and neither did they construct sub-Saharan Africa as different from Africa north of the Sahara. They adopted a Pan-Africanist view of the black experience, a view driven by the valid assumption that slavery and colonialism and the racist oppression they engendered were borne out of the international capitalist system of economic exploitation. This reading of capitalist exploitation allowed prominent leaders of the civil rights movement in America and activists like Paul Robeson, Max Yergan, Alphonse Hunton, W. E. B. Du Bois and Walter White to insist that 'anti-colonialism and civil rights marched together'. Through their civil rights struggles, these leaders forged a link between anti-racism and anti-colonialism, arguing that 'racism [was] located in the history of slavery, colonialism, and imperialism' (Von Eschen 1997: 155). They established a black intellectual tradition that interpreted history so as to change the situation of oppressed people. Today, we interpret history but do not seek to make a difference.

Thus, the advent of white Africanists in the study of Africa led to several changes in the study of Africa in the US. Apart from the dominance of white Africanists, their interest to serve American foreign policy and to interpret Africa to a largely white American audience, Africanists also assumed the expert position on Africa. Predictably, African Studies subsequently tried to silence other narratives of Africa by generally omitting 'any reference to the long standing tradition of African Studies at historically black colleges and universities, only rarely giving a nod to African American professional and lay scholars of Africa, and seldom acknowledging the existence of epistemic communities based in Africa' (Robinson 1997: 169). The result has been a neglect of the pioneering role of HBCUs like Fisk, Lincoln, Howard, Morehouse, Wilberforce, Spelman and Atlanta and an explicit statement, associated with Phillip Curtin, that 'at the end of the Second World War North America had no real community of scholars specializing in Africa' (Curtin 1971: 358). ${ }^{8}$

There also occurred a concentration of research resources in African Studies programmes located in Historically White Universities (HWU), and with this, the preponderance of white perspectives on Africa. Thus, the main outlets of knowledge on Africa are concentrated in Africanist publishing houses, books and journals (Veney and Zeleza 2001). A review of five mainstream Africanist journals showed that Africans on the continent rarely get published in these outlets largely due to the subjective predilections of editors and Africanist networks (Zeleza 1997). Also, African Studies asso- 
ciations, research networks and publication outlets increasingly fell in the hands of the better-resourced networks and schools. This has made it very difficult to promote alternative perspectives on Africa other than mainstream perspectives of Africanists. It is because of these politics of knowledge production that 'the Africa of African Studies has become the sub-Saharan contraption examined through the gaze of modernization and development' (Zeleza 2003: 190). In adopting the modernisation approach, African Studies has promoted the study of Africa by analogy. ${ }^{9}$ Africa is studied on the basis of what it is not rather than what it is (see Mamdani 1996). The Africa of African Studies can most appropriately be described as the Africanist Africa. It is different from the Africa many of us live in.

Is it any wonder then that African Studies always seem flawed in the eyes of most African scholars. The primary reason for this is that its canon, content and theory are based on American foreign interests rather than its relevance for Africa and its concern for social struggles on the continent. For several decades, African scholars have questioned the relevance of African Studies to Africans. Some correctly believed that the study of Africa was simply a career path to some Africanists. ${ }^{10}$ Yet the charge of irrelevance persists in the new millennium. This time, it is because of the continued disengagement of African Studies from Africa and African scholars, by its unresponsive attitude towards issues of social justice on the continent ${ }^{11}$ and by its patronising and matronising inclination towards Africans. In the view of keen African observers, African Studies continues to be 'less about Africa and more about the United States' (Zeleza 2003: 180). Is it surprising that 'African scholars based on the continent often do not recognize the Africa that is analysed and invoked in ASA panels'? (Kassimir 1997: 161). ${ }^{12}$

This long discussion of the character of Africa studies in the US is meant to suggest (i) that it has not played its central role of informing the American public about Africa and (ii) that it has not played its role in extending and connecting African struggles to similar struggles waged by other disempowered people of the world. On the contrary, it has been concerned with the collection and cannibalisation of raw data that are then used to test pet theories designed in disciplines. Often, these data are lodged in Africana collections and never get out to the public where they are really needed. Publications are also churned out with breathtaking regularity but most of them are written with the reviewers and publishers in mind (Veney and Zeleza 2001). Authors whose works show a commitment to the actual social struggles on the continent find it difficult to penetrate publishing houses and journals. These authors opt to publish with obscure independent publishers, a fact that limits the circulation of their ideas. ${ }^{13}$ Indeed, one of the glaring 
problems in the study of Africa in the US is that African publications are conspicuous by their absence on most course outlines used in American universities. As a result, American students learn only from American/European authors of Africa. This gives the misleading impression that Africa has no authors and perpetuates the belief that the only credible ideas about Africa come from non-Africans.

\section{The Experience of Black Studies}

There are two possible ways through which interested young African-Americans can learn about Africa. The first is obviously from African Studies. This is so given the distance between the continent and the US. The other is from Black Studies. Other channels like the dominant media are full of alarming misrepresentation of Africa and do not constitute a good option. A third way which is briefly discussed below but which is more effective is the learning that goes on within African-American communities themselves. But even African Studies has historically been unfriendly and suspicious of the African-American presence. Melville Herskovits, the well known American anthropologist, discouraged African-Americans from studying Africa, invoking the excuse that they lacked the 'requisite' objectivity. ${ }^{14}$ Thus, comparatively few African-Americans study Africa from within African Studies. Many are disappointed by its content. They are suspicious of the dominant racial ideologies within the subject. Others are crowded out of the field by advantaged white students who are exposed to a wider curriculum at high school because of racial advantages embedded in the US education system. For others, it is a simple principle of who ought to teach African issues. This category includes people who are suspicious of the reasons Africa is taught in the US in the first place. All these factors have contributed to the institutional and pedagogical disconnection between programmes of African Studies and Black Studies in US universities and the consequent racial division of labour in which African Studies is dominated by white teachers.

African Studies has a double disengagement from Africa that explains the persistent ignorance many people in the US exhibit about it. The first disengagement separates the practice of African Studies from its object of analysis. I refer especially to the distance between its institutions in the US or Europe and the field of research in Africa. Considering US segregationist tendencies, I also refer to the distance between Africanists and black people, most of whom are segregated away from white schools and residences. This distance renders the issue of how to understand the 'lived experience' within Africa (discussed in this volume by Nana Akua Anyidoho) of immedi- 
ate significance. Can Africanists attain the requisite connection to the lived experiences in Africa so as to claim substantive knowledge of the continent?

In order to access data on Africa, many Africanists have had to rely on government publications or on research assistants in Africa. While these sources are useful, their reliability is often questionable. Some sources come with major gaps while others are generated through flawed research processes. The gaps and flaws can be checked by a constant observation of the lived experiences of people on the ground and by a detailed understanding of the way people live and express their concerns. The nearest Africanists have come to achieving sustained connection to the lived experience in Africa was through the participant observation procedure. It is therefore of concern that during the last two decades, very little of the western publications on Africa were based on actual research on the continent. ${ }^{15}$ Without adequate funding, many Africanists make short trips to Africa or prefer to use government sources, some of which are compiled from faulty research. How reliable is this research in providing accurate readings of African realities? To what extent, then, are western students taught up-to-date and reliable histories of Africa?

If we concur that the primary concern of African Studies has been to expand 'Western knowledge of African culture, politics, humanities, and the sciences', then there are two bases of evaluating its success: (i) at the level of American foreign policy towards Africa, and (ii) with regard to the general American public understanding of Africa. If what we hear from American officials and from the American public is anything to go by, African Studies has failed in these two areas. Instead, Africanists, like other area studies specialists, are still trapped in the Cold War culture of serving American foreign policy interests. The pressure to serve American foreign interests has grown over the last couple of years following the terrorist attacks in New York and Washington D.C., and Africanists are busy defending themselves to demonstrate how valuable African Studies is to the US. ${ }^{16}$ One consequence of 9/11 was heightened US phobia against aliens. This has been played out of proportion by legislation like the Patriot Act which, to use David Cole's recent title, labels all foreigners as 'enemy aliens' (Cole 2003).

This phobia has a fertile breeding ground in the US public understanding of itself and its relationship to the rest of the world. Many Americans still think of America as the world. Their media 'is intensely inward looking and self-absorbed' and does not provide a more informed alternative. Thus, Americans define America's future as everyone's future. As a recent study argues, 'at the heart of relations between America and the rest of the world stands a problem of knowledge. In precise terms, we call it the problem of 
"knowledgeable ignorance": knowing people, ideas, civilizations, religions, histories as something they are not, and could not possibly be, and maintaining these ideas even when the means exist to know differently' (Sardar and Davis 2002: 11-12).

With regard to Africa, the situation is worse. Many Africans in the US are confronted with weird questions and arrogant opinions about Africa. Indeed, many Americans still get surprised that an African who arrives direct from the continent can speak 'very good English'. This ignorance is not confined to the poor Americans, especially minorities who have no easy access to information. It is evident in upper and middle class families and is threatening to become a culture among the ruling class. US foreign policies on Africa reveal such feigned or deep-seated ignorance (Apraku 1996 for details). As this culture continues to grow, it further emphasises that either African Studies is yet to achieve its two most important goals or that its agenda has very little to do with Africa. This has fuelled African suspicion of the Africanist enterprise.

The second disengagement is between African Studies and Black Studies. There are numerous dimensions to this problem. But this distance should be traced to the entry of white Africanists into the study of Africa and the concentration of federal and private foundation funding into mainstream white institutions like University of California, Los Angeles, Northwestern University, Boston University and the University of Wisconsin at Madison. This development had the effect, in Deborah Amory's words, of creating 'a racial division of labour between African Studies and Afro-American Studies where white people did African Studies, while black people did Afro-Am [sic]' (Amory 1997:102). This disengagement has meant that Africa is studied independent of its diaspora. Predictably, the distancing has been very costly to the black Pan-African heritage. This distancing partly explains why a whole generation of African Americans has grown in ignorance of the actual African experiences on the continent. Filtered as these experiences are through non-African eyes and packaged through theoretical frameworks that have little to do with the social and economic struggles and celebrations on the continent, the knowledge produced says more about mainstream American perceptions, attitudes and interests than about Africa. It is this mainstream that excludes and marginalises the position and views of African-Americans.

Previously, many young African-Americans learned about Africa through the heritage of black learning in black communities. This heritage was transmitted by word of mouth, through black newspaper commentaries, and by black intellectual publications. Patricia Hill Collins has shown how black women shaped this heritage. Indeed, going by the statistics of male blacks in 
jail in the US, one cannot ignore the role of black women in shaping and transmitting what knowledge there was in black neighbourhoods about Africa, knowledge that was institutionalised in the well-publicised Pan-African conferences. Within the black communities, Africa was not just created as an authentic reality, it was also imagined through stories and folk tales that recreated it as a site of peace, harmony, splendour and abundance. This recreation lay at the heart of African American imagination of Africa as home. It also lay at the heart of a thriving aspiration of black unity that animated Pan-Africanism. Pan-Africanism is about unity based on some identity, but as Philippe Wamba shows, that identity is not cultural, it is 'an identity of Passions' (Wamba 1999: 29). However, as Black Studies was formalised and integrated in mainstream US schools and colleges, this heritage has suffered some damage.

Black Studies, even as it disconnects from the heritage of learning in black communities, continues to produce and provide knowledge about the black experience in the US. In the university, Black Studies has its full agenda that limits how much can be taught about Africa. According to Marable Manning, Black Studies was based on a core black intellectual tradition that was 'descriptive', 'corrective' and 'prescriptive'. It aimed to 'richly describe the contours of black life and history ... from the point of view of black people themselves', to 'correct the racist stereotypes and assumptions of black genetic or cultural inferiority' and to 'eradicate racism and empower black people'. This tradition was not just about interpretation, it emphasised action. It emphasised the need to 'utilize history and culture as tools through which an oppressed people can transform their lives and their society' (Marable 2000: 189). Its scope was transcontinental, considering black experiences across the world as connected experiences. But the integration of Black Studies in mainstream disciplines and schools has come at a cost for this translocality. The emphasis has shifted from the core agenda of black intellectual tradition to literary and cultural studies. Questions of political economy, the organisation of power and the concrete understanding of race are increasingly delinked and sidelined. The purpose of such delinking is best known to its practitioners because there is no way cultural studies can proceed without a concrete understanding of political economy. In an age where globalisation is seen more in terms of cultural flows, where language games replace concrete analysis and where the gains of the civil rights era are rolled back by an abnormal fixation on terrorism, one need not wonder why political economy approaches are being de-emphasized.

Also, recent trends in black intellectual work have attempted to introduce invidious divisions between Black Studies and African scholarship on the 
continent and between African-Americans and Africans in the US. These divisions are not new; they have a history that is ably described in Eschen's study of Race Against Empire. She locates this division in the Cold War politics that framed black protests during the American civil rights struggles as a threat to US security, not segregation itself (Von Eschen 1997: 126). This way of framing the problem encouraged sections of African-American populations to disentangle the struggles against racism in the US from the wider international struggles against imperialism in the world. It resulted in the view, expressed by Walter White, that 'Negroes are Americans' and that 'in the event of any conflict that our nation has with any other nation, we will regard ourselves as Americans and meet the responsibilities imposed on Americans' (Von Eschen 1997: 112). In other words, Blacks were Americans first, and anything else was secondary. This attempt to treat civil rights struggles and nationalism as separate is carried on today by, among others, Gilroy in his Black Atlantic.

The view that African-Americans are Americans first and only secondarily black has led to an atmosphere of competition between Africans and African-Americans. It must be acknowledged that transatlantic relations between African and African-Americans 'is nothing if not complex, layered, and twisted in fascinating and sometimes problematic ways'. Based on the fact that about 500 years separate African culture from that of AfricanAmericans, it is understandable why these relations would be laced by stereotypes, suspicion, and competition. Many African-Americans are surprised and even embarrassed by how different Africa is from the Africa of stories and folk tales, the Africa they consumed in black communities. There are several examples of blacks who have openly expressed disappointment with Africa, including Keith Richburg, at the time the Nairobi-based black reporter of the Washington Post. Following the Rwanda genocide, Richburg thanked the accident of history that made him an American (Richburg 1997). Richburg failed to understand that Africa could not have lived up to his expectations 500 years after his ancestors made that horrific voyage into slavery. Other African-Americans who have confronted Africa with rigid expectations have similarly been disappointed and embarrassed. ${ }^{17}$

In the academy, this atmosphere of suspicion is associated with a politics of divide and rule in African Studies. In her presidential address to the ASA in 1997, Gwendolyn Mikell pointed at Africanists, observing that 'As we look backward, it becomes clearer that Americans were only slightly less uneasy about how to relate to the first generation of African scholars than they were about how to relate to African American Africanists and it is this unease that must be combated as we deal with the issue of mutuality' (Mikell 1999: 5). 
Why have Africanists been less uneasy with Africans than African-Americans? First, many Africans treat access to mainstream American schools and research institutes as a privilege. Forced into political or economic exile by poverty and authoritarian regimes at home, many Africans are offered residence in the US through the patronage of leading Africanists. Also, recent research shows that it has been the preoccupation of Africanists since the 1960s to date to divert the traffic of African students in the US from historical admission in HBCU common in the times of Kwame Nkrumah, for instance, to HWU. In contrast, African-Americans demand equality in accessing mainstream schools as a right. Many are conscious of their rights which they proceed to demand and fight for. Some Africans have joined them in this struggle, although most do and some remain unaware of this. African-Americans have been able to bring their demands onto the table and claim the resources that they, as ex-slaves or descendants of slaves, helped create. Thus compared to Africans who arrive in search of political or economic refuge, and who rely on the goodwill of their white hosts, AfricanAmerican demands have a firm grounding in civil rights. Their demand has threatening potential for Africanists who control access to African Studies.

There are also struggles and conflicts between African migrants to the US and African-Americans that undermine transatlantic links. These rotate around stereotypes and ignorance of each other. This is fostered as blacks continue to see each other 'through the eyes of the other', as Du Bois put it. 'Unable to penetrate the veil of racism, many migrants consider African Americans lazy, violent and obsessed with race while many African-Americans see the migrants as inferior, ignorant and uncivilized' (Njubi 2002: 12). This stereotyping has resulted in open conflict over jobs as the case of recent struggles at Virginia State University, a historically Black university, showed. Given this state of affairs, and the fact that mainstream schools find Africans less threatening than African-Americans, the latter 'are beginning to justifiably feel like a "minority within a minority"'(Njubi 2002: 12). The presence of African migrant has in a sense acted as a valve to employ blacks, but it is a strategy that ensures the further marginalisation of nativeborn African-Americans. African scholars have not always been sufficiently sensitive to this development. In fact, others like Tunde Adeleke, have arrogated themselves the right to (mis)interpret African-American experiences and perceptions to largely white audiences. ${ }^{18}$

The more sensitive and complex problem in African and African-American relations concerns the memory of slavery. This continues to fuel debate and suspicion among black people. The fruitful side of this debate focuses on questions of memory and how slavery should be remembered. The slave 
castles in Ghana provide a good example. The struggle over the meaning of Elmina Castle in the Cape region is emblematic of the fragmented memory of the black experiences. While for Ghana, the castle represents a long history stretching from 1482 when the Portuguese built it, to its 1637 Dutch capture, and the 1872 British occupation and finally to independent Ghana, African-Americans are attracted to it because of the slave dungeons through which their ancestors were shipped into the holocaust of slavery. As Bruner argues, the African-American interest is obviously restricted to an era in the long history of the castle from a trading post to slave dungeon to military fortification to colonial administrative centre to prison, school, and office (Bruner 1996: 292). This has repeatedly raised the question of what memory of Elmina should be preserved especially when its history offers conflicting possibilities. In 1994, this conflict of meaning climaxed as Ghana sought to renovate the castle for the sake of tourism. As a country with deep economic challenges, Ghana has often viewed the castle in economic terms as a tourist attraction. Ghanaians do not always, for understandable reasons, share the African-American focus on the castles as historic representation of the painful black experience of slavery. In any case, some African-Americans are inclined to blame locals for the evil of slavery since their ancestors were sold into slavery by locals. For some Ghanaians, African-Americans have no stake in the castle because, like other visitors, they are obruni (foreigners) like other Americans but unlike black visitors from within the continent. Some Ghanaians complain about African-American indifference to their economic situation and wonder at the emotions of black visitors to the castles.

The study of slavery has therefore produced two broad intellectual trends. On the one hand, it has led to some constructive engagement and collaboration between Africans and African-Americans while, on the other hand, it has spawned suspicion. In the first trend, there is work that engages the notions of memory not simply as a form of remembering but also as a domain of forgetting. This literature appreciates the contested meaning of the legacies of slavery. As the work of Kofi Anyidoho and Sandra Richards on Memory and Vision: Africa and the Legacy of Slavery under the aegis of the CODESRIAAfrican Humanities Institute illustrate, this dimension of the debate brings into fruitful dialogue both African scholars on the continent and the diaspora scholars and renders the distinction between them less useful. But, in the second trend, there are those African-Americans who blame Africans for the horror of enslavement and demand apologies. Represented by Henry Louis Gates Jr.'s television series Wonders of the African World, and Achille Mbembe's 'African Modes of Self-Writing', this version of the problem is rooted in unspoken mainstream institutional racism propagated through 
conservative black intellectuals and deploys US racial categories to analyse African identities. In the Wonders series, Gates Jr. blamed Africans for the horrendous slave trade and coerced African informants into acknowledging that Africans were indeed solely responsible for the trade. He further extracted an apology from another informant over their role in enslaving African-Americans.

Gates Jr. was following a well-trodden tradition. J. D. Fage had argued that slavery already existed in Africa and Europeans simply built on an existing system. ${ }^{19}$ John Thornton writes to 'support the idea that Africans were active participants in the Atlantic world, both in African trade with Europe (including the slave trade) and as slaves in the New World'. ${ }^{20}$ Thornton argues that slave trade was firmly in the control of Africans. For him, Europeans lacked the necessary military power to take effective control of the trade and the use of slaves was already prevalent in Africa and its political system already had legal relations of slavery for political purposes. But Thornton's findings are only applicable to Africa before 1680. Like Fage, he fails to note that after 1680, the trans-Atlantic slave trade became 'something radically new and unimaginable' (Depelchin 1999: 170).

The main difference between Thornton and Gates Jr. is racial. As a black person, Gates Jr. can say things about Africans that a white person would prefer to whisper in privacy. Thus, his role in this debate is one that African Studies reserves for certain cadre of African intellectuals whose thinking is permissive enough to blame the victims. No wonder, the African related discussion of 'Wonders' boomed with questions on Gates Jr.'s pernicious intentions. African-American critics of Gates Jr. described him as 'a black ambassador of Eurocentrism and white supremacy' who demonstrated 'a severe detachment from African people' (Tobert quoted in Magubane and Zeleza 2002: 53). Regarding Gates Jr.'s claim that Africans were largely responsible for slave trade, critics observed that the claim was ahistorical and decontextualised. Some critics correctly questioned Gates Jr.'s credentials as a historian or an Africanist. Wayne C. Jones wondered: 'On what and whose authority did he become an expert in anything about Africa or Africans?' (Zeleza 2003: 329). Of course, many critics rightly thought that the superficiality and misrepresentation of the 'Wonders' series were intentional. As Lawrence Mbogoni observed, 'I would not accuse him of not knowing what he was doing. He had a specific, may I say, ideological objective in doing this program and he knew what he was doing or wanted his program to achieve' (Zeleza 2003: 330). And of course, the PBS knew why they chose a professor of English to do a series on African history! The aim of such a series will remain up for speculation. But the objective of drawing a 
wedge between Africans and African-Americans by scampering over European culpability has been noted. The responses from Africans and AfricanAmericans discredited this objective.

Obviously, all black scholars do not agree on what use our scholarly endeavours should be put or on the future of black unity. Indeed, a healthy debate about some of the basic assumptions, frameworks and methodologies is useful for a black intellectual tradition. But the aim of these debates should be to better the welfare of black people and to enhance the transatlantic links that will bridge the mutual ignorance of black experiences. Disagreements are unhealthy if their aim is to disempower our struggle entrench imperialism and dismantle the insurgent spirit of black people.

This article has shown the many ways in which African Studies has been a problem in the construction of knowledge about Africa and its diaspora. It has also shown how relations between black people in Africa and the US have worsened because of the knowledge gap across the Atlantic. The study does not, however, vouch for African Studies controlled exclusively by black people. Africa has benefited from non-black perspectives on Africa and crossregional and interracial collaborations. Some of the books used in the study of Africa in Africa are actually authored by white Africanists and many black scholars of Africa have gone through the helpful guidance of well-meaning Africanists. Over the years, as Africanist books became more expensive and African libraries collapsed under the weigh of structural adjustments, younger African scholars have survived without many of these links. As such, the role of African Studies among some of these scholars has diminished greatly. This generation of African scholars is more interested in a real transition to equality, a respect for the place of the African scholar and black people in African Studies. This generation is less understanding than the previous generation that studied abroad and depended on western patronage. In its endeavour to have control over the study of their societies, this generation is unlikely to be as tolerant as the previous ones. That explains why this article has generalised the critique by lumping together committed white friends of Africa with those whose baseline goal is career advancement or supplying information to those organisations that are implicated in destroying Africa's heritage and its future. For this sweeping condemnation, I can do no better than quote Mkandawire:

If we do not always seem to appreciate these efforts by others to understand Africa and if our demands to be heard seem a trifle extravagant, it is because too often in our history the quest for knowledge of Africa has been motivated by forces or arguments that were not for the promotion of human understanding, let alone the welfare of the Africans - there were at times to 
reinforce preconceived prejudices, or for mastering instruments of domination of our societies. Although much has changed over the years, considerable research driven by these motives still exists, feeding African suspicions of even those whose quest for knowledge about Africa is driven by genuine interest in understanding the African continent as an important site for the performance of the human drama (Mkandawire 1997).

\section{Conclusion}

In conclusion, let me state the two things. First, I do not subscribe to the view that African 'voices' need to be heard more in African Studies. Mainstream African Studies in the US has the amazing capacity to ignore those it does not want to hear and to imagine that the voices eventually die when they are ignored. Black people have spent too much time trying to be heard and engaging in what is too often a fruitless vertical dialogue. In short, vertical dialogue has not worked. We need to enhance horizontal dialogue among all people who are concerned with fighting the abuses meted out against the lower classes of people of which black people are a majority. I use lower classes for the sake of inclusivity. We need all those committed and true friends of a just insurgent cause against the ruling classes of the world and their beneficiaries. The ruling class has a token space for black people and we must be wary of them to. As Patricia Hill Collins says, the selections and authorising of a few representative black people can be an effective way of 'stifling subordinate groups' (Collins 2000: viii). Horizontal dialogue will involve committed black people and all those who genuinely identify with the cause. It is a dialogue that once thrived, linking Asia, Africa, and the black diaspora. It is a dialogue that can thrive again. Already, these initiatives have started with one Africa organisation, CODESRIA, bringing about a series of Afro-Asiatic dialogues.

Secondly, it must be stated that there are no people in history who have developed pride in their past and constructed their identity on the basis of knowledge produced for them by others. My contention is that the international intellectual division of labour can be changed if black people seize on the opportunities presented for horizontal dialogue among Africans. African Studies has fed its audiences with images of Africa's hopelessness, wars, diseases, famines, its abnormal mutilation of women genitalia, its genocides, street children, etc. The American audience knows very little about the virtues of Africa, its successes, victories and achievements. Many Africans know that though their lives were poor by American standards, America was not their index of measuring comfort, safety and wealth. The grass-thatched and mud-walled house where we spent most of our youth and early adult life 
was the safest place on earth. For in these houses, we could sleep without latching the door and have the best sleep ever. Unfortunately, this is the Africa that you will never get in the books or on CNN. It is an Africa that can best be presented by one who lives and experiences it or by one with sustained intimate connection with it. It is this Africa that carries the pride and connection underlying the Pan-African ideal.

\section{Acknowledgments}

This is a revised version of a paper presented at the 30th CODESRIA Anniversary Celebrations Conference on 'Intellectuals, Nationalism and the PanAfrican Ideal' held in Dakar, Senegal from 8 to 11 October 2003. It has benefited from comments and suggestions from colleagues including Nana Akua Anyidoho, Mshai Mwangola, Cedric Mackay, Matthew Quest, David Donkor, Kwame Henry Dougan and Hannington Ochwada. During the conference, I also benefited from Kofi Anyidoho's suggestions. The usual caveats apply.

\section{Notes}

1. Ivan Van Sertima, They Came Before Columbus, New York: Random House, 1976 shows that the African presence in America predates the slave trade.

2. This ignorance is susceptible to journalistic stereotypes, those peddled by the visual images of Hollywood, and yet others found in academic books. Consequently, many westerners think of Africa as a primordial place where Africans still live in caves or on trees. Call this the Africa of The Gods Must Be Crazy. In the US, people wonder how someone could manage living in such a continent allegedly dominated by disease, wars and ignorance. After all, did not George Bush Jr. say that 'Africa is a nation that suffers from incredible disease'? Or did not the London magazine The Economist find it apposite to headline its cover story on Africa in 2000 'Hopeless Continent'? Furthermore, there are books about Africa that paint the picture of anarchy and chaos, books that argue that Africa works through disorder. These books hold the image of Africa as the 'heart of darkness'. Kaplan's The Coming Anarchy, for example, is replete with images of crime, horror, death and darkness. And Kaplan was so important that his speculations on Africa were faxed to every American embassy in Africa during the Clinton era. At the academic level, Jean-François Bayart, Patrick Chabal and their colleagues also write in this mode. They emphasise the increasing normalisation of criminal activities in Africa as the particular path of Africa's development. Arguing that the continent is sliding back into the heart of darkness, they suggest that the consequences of this return, including dissidence, war and banditry, will not necessarily lead to the destruction of the state but to its formation. This, for them, is Africa's unique way. Africa responds to its own internal logic in which disorder prevails 
and its instrumentalisation to achieve the designs of political actors has been normalised (Bayart 1999; Chabal and Daloz 1999).

3. Africa Research Group, African Studies in America - The Extended Family: A Tribal Analysis of US Africanists; Who They Are, Why to Fight Them, Cambridge: Mass. 1970.

4. For an excellent critique of this linear reading of time, see Souleymane Bachir Diagne, 'On Prospective: Development and a Political Culture of Time', in Africa Development, Vol. XXIX, no. 1, 2004, pp. 55-69.

5. This paragraph is based on the excellent work of William G. Martin and Michael O. West, eds., Out of One, Many Africa's: Reconstructing the Study and Meaning of Africa, Urbana and Chicago: University of Illinois Press.

6. For an impressive array of black scholarship on Africa, see Elliot P. Skinner, 'Afro-Americans in Search of Africa: The Scholars' Dilemma', in Pearl T. Robinson and Elliot P. Skinner, (eds.) Transformation and Resiliency in Africa, Washington D C: Howard University Press, 1983; Faye V. Harrison, 'The Du Boisian Legacy in Anthropology', in Critique of Anthropology, Vol. 12, no. 3, 1992 and Paul Gilroy, The Black Atlantic: Modernity and Double Consciousness, Cambridge, MA: Harvard University Press, 1993.

7. Pearl T. Robinson, 'Area Studies in Search of Africa', UCIAS Edited Volume 3, Article 6, 2003 does very well in reviewing black scholarship on Africa and the politics of knowledge production in Area Studies with a specific focus on Africa.

8. This neglect of HBCU and the epistemic communities in Africa is particularly glaring in Jane I. Guyer, African Studies in the United States: A Perspective, Atlanta: African Studies Association Press, 1996.

9. Mahmood Mamdani showed the validity of this claim in his review of Goran Hyden's study titled No Shortouts to Progress. See Mamdani, 'A Great Leap Backward', in Eastern African Social Science Review, Vol. 1, no. 1, 1984.

10. As early as 1970, Smock charged that American researchers pursued research that had little relevance for Africa and that only served to further their own careers (Smock 1970: 24). Victor Uchendu warned that African Studies 'is nothing if it provides no service to Africa. It served the interests of colonial governments; it has a responsibility to serve independent Africa, a major consumer and audience of its studies' (Uchendu 1977: 10).

11. For some exceptions to this disengagement, see Allen Isaacman, 'Legacies of Engagement: Scholarship Informed by Political Commitment', in African Studies Review, Vol. 46, no. 1, 2003, pp. 1-41.

12. Nothing illustrates this better than the fact that there are no centres/programmes of African Studies in African universities modelled along the lines of those in the North except the racialised ones in South Africa. Most universities on the continent teach Africa as a core part of the disciplines. For us on the continent, Africa is not an area different from other areas. Its experience is a central part of the overall human experience. The few institutes of African Studies in Africa 
are meant to emphasise Africa as a point of departure to understanding the human experience, not to lodge Africa as a marginal and separate area that is different from the larger human experience.

13.Indeed, a few concerned publishers have come up that regularly rescue manuscripts of this cadre. They include CODESRIA which rescued Jacques Depelchin's (1992) engaging study of the Belgian plunder of Zaire and Africa World Press which has consistently published manuscripts rejected by mainstream publishers. But once published, these studies rarely appear in course schedules in mainstream western universities. When they appear, it is often clear to those more conversant with Africa-based publications that the Africanist responsible has actually not browsed, leave alone read, them. Thus, for instance, one easily comes across a reading list prepared in 2004 for African history comprehensive examination for graduate students at a Northern university that lists Tiyambe Zeleza, 'A Modern Economic History of Africa, Volume 2: The Twentieth Century (Dakar: CODESRIA, 1997)'. Of course, one could excuse this one for having some interest in an African writer; many others actually do not care.

14. The use of 'racial mediated hierarchies' to limit African-American participation in research expeditions was deployed to dismiss formidable black scholars like Alain Locke and Leo Hansberry. See Robinson, 'Area Studies in Search of Africa', pp. 8-9.

15.For a study on the flawed relationships between armchair researchers and research assistants, see Margo Russell and Mary Mugyenyi, 'Armchair Empiricism: A Reassessment of Data Collection in Survey Research in Africa', in African Sociological Review, 1, 1, 1997. The argument that many Africanist publications were not based on actual research in Africa is derived from John McCracken, 'African History in British Universities: Past, Present and Future', in African Affairs, Vol. 92, no. 367, (April 1993), pp. 239-253 which is specific to the history.

16.The American House of Representatives' Subcommittee on Select Education Hearing on 'International Programs in Higher Education and Questions about Bias' sitting on June 19, 2003 considered and proposed to create an International Education Advisory Board with appointed members from homeland security, the Department of Defense and the National Security Agency, 'to increase accountability by providing advice, counsel, and recommendations to Congress on international education issues for higher education'. Stated simply, this board is meant to monitor Title IV funded programmes and ensure they teach and research issues that serve American security and foreign policy interests. See this link for details: http://edworkforce.house.gov/hearings/108th/sed/ titlevi61903/wl61903.htm

17. Sections of this paragraph are from Philippe Wamba, Kinship: A Family Journey in Africa and America, New York: Plume, 1999. 
18. See Anthony Kwame Appiah, In My Father's House: Africa in the Philosophy of Culture, New York: Oxford University Press, 1992 and Tunde Adeleke, UnAfrican Americans: Nineteenth-Century Black Nationalists and the Civilizing Mission, Lexington: University Press of Kentucky, 1998. Adeleke, for instance, has been critiqued for a lack of historical contextualisation of his argument which leads him to exaggerate his main conclusions. See Wilson J. Moses's review in Labor, no. 49, Spring, 2002, p. 310 also found at http:// www.historycooperative.org/journals/llt/49/

19. J. D. Fage, 'Slaves \& Society in Western Africa', Journal of African History, 21, 3, 1980. Also see Joseph E. Inokori, 'Slavery in Africa and the Transatlantic Slave Trade', in Alusine Jaallon and Stephen E. Maislish, eds., The African Diaspora, Texas: A \& M University Press, 1996 for a different perspective.

20. John Thornton, Africa and Africans in the Making of the Atlantic World, 1400-1680, New York: Cambridge University Press, 1992, p. 7. For a critique see Jacques Depelchin, 'Braudel and African History: Dismantling or Reproducing the Colonial/Capital Paradigm', in William G. Martin and Michael O. West, eds., Out of One, Many Africa's: Reconstructing the Study and Meaning of Africa, Urbana and Chicago: University of Illinois Press, 1999.

21. For a perspective on what the young generation of African scholars expect from their senior scholars, see Mshaï S. Mwangola, 'Nurturing the Fourth Generation', Paper Presented at the CODESRIA 30th Anniversary Celebrations Conference on 'Intellectuals, Nationalism and the Pan-African Ideal' in Dakar, Senegal, October 2003. The revised version of this paper is included in this issue.

\section{References}

Adeleke, T., 1998, UnAfrican Americans: Nineteenth-Century Black Nationalists and the Civilizing Mission, Lexington: University Press of Kentucky.

Amory, D., 1997, ‘African Studies as American Institution', in Akhil Gupta and James.

Ferguson, eds., Anthropological Locations: Boundaries and Grounds of a Field Science,Berkeley: University of California Press.

Anyidoho, N. A., 2003, 'Identity and Knowledge Production in the Fourth Generation', Paper Presented at the CODESRIA 30th Anniversary Celebrations Conference on 'Intellectuals, Nationalism and the Pan-African Ideal' held in Dakar, Senegal from 8-11 October 2003.

Appiah, K. A., 1992, In My Father's House: Africa in the Philosophy of Culture, New York: Oxford University Press.

Apraku, K., 1996, Outside Looking In: An African Perspective on American Pluralistic Society, Westport: Connecticut: Praeger.

Bayart, F. et al., 1999, The Criminalization of the State in Africa, Oxford: International African Institute in association with James Currey; Bloomington: Indiana University Press. 
Brantlinger, P., 1989, 'Victorians and Africans: The Genealogy of the Myth of the Dark Continent', in Critical Inquiry, 12.

Bruner, E., 1996, 'Tourism in Ghana: The Representation of Slavery and the Return of the Black Diaspora', in American Anthropologist, Vol. 98, no. 2.

Chabal, P. \& Daloz, J., 1999, Africa Works: Disorder as Political Instrument, Oxford: International African Institute in association with; James Currey and Indiana University Press.

Collins, P. H., 2000, Black Feminist Thought: Knowledge, Consciousness, and the Politics of Empowerment, New York: Routledge.

Curtin, P., 1971, 'African Studies: A Personal Statement', in Africa Studies Review, Vol. 14 , no. 3 .

Depelchin, J., 1999, 'Braudel and African History: Dismantling or Reproducing the Colonial/Capital Paradigm', in William G. Martin and Michael O. West, eds., Out of One, Many Africa's: Reconstructing the Study and Meaning of Africa, Urbana and Chicago: University of Illinois Press.

Depelchin, J., 1992, From the Congo Free State to Zaire: How Belgium Privatized the Economy: A History of Belgian Stock Companies in Congo-Zaïre from 1885 to 1974, Dakar: CODESRIA Book Series, 1992.

Fage, J. D., 1980, 'Slaves and Society in Western Africa', Journal of African History, Vol. 21, no. 3 .

Gilroy, P., 1993, The Black Atlantic: Modernity and Double Consciousness, Cambridge, MA: Harvard University Press, 1993.

Gough, K., 1967, 'Anthropology: Child of Imperialism', in Monthly Review, Vol. 19, no. 11 .

Gough, K., 1968, 'New Proposals for Anthropologists', in Current Anthropology, Vol. 9.

Harrison, F. V., 1992, 'The Du Boisian Legacy in Anthropology', in Critique of Anthropology, Vol. 12, no. 3.

Inikori, J. E., 1996, 'Slavery in Africa and the Transatlantic Slave Trade', in Alusine Jaallon and Stephen E. Maislish, eds., The African Diaspora, Texas: A \& M University Press.

Kassimir, R., 1997, 'Internationalization of African Studies: A View from the SSRC', in Africa Today, Vol. 44, no. 2.

Liu, T., 1991, 'Teaching the Differences among Women from a Historical Perspective: Rethinking Race and Gender as Social Categories', Women's Studies International Forum, Vol. 14, no. 4.

Mafeje, A., 1996, Anthropology and Independent Africans: Suicide or End of an Era, Dakar: CODESRIA Monograph Series 4/96.

Magubane, Z. \& Zeleza, P. T., 2002, 'Dr. Gates, We Presume: The Interplay of Text, Audience, and Narrator in Wonders of the African World', in ChemChemi: International Journal of the School of Humanities and Social Science Kenyatta University, Vol. 2, no. 1. 
Mamdani, M., 1998, Teaching Africa: The Curriculum Debate at UCT, Cape Town: University of Cape Town Centre for African Studies.

Mamdani, M., 1996, Citizen and Subject: Contemporary Africa and the Legacy of Late Colonialism, Princeton, NJ: Princeton University Press.

Marable, M., 2000, 'A Debate on Activism in Black Studies', in Manning Marable, ed., Dispatches from the Ebony Tower: Intellectuals Confront the African American Experience, New York: Columbia University Press.

McCracken, J., 1993, 'African History in British Universities: Past, Present and Future', in African Affairs, Vol. 92, no. 367.

Mikell, G., 1999, 'Forging Mutuality: The ASA and Africa in the Coming Decades', in African Studies Review, Vol. 42, no. 1.

Mkandawire, T., 1997, 'The Social Sciences in Africa: Breaking Local Barriers and Negotiating International Presence', M.K.O. Abiola Lecture delivered at the ASA 50th Anniversary Celebrations. in African Studies Review, Vol. 40, no. 2.

Mudimbe, V. Y., 1988, The Invention of Africa, Bloomington: Indiana University Press.

Mwangola, M. S., 2003, 'Nurturing the Fourth Generation: Defining the Historical Mission for our Generation', Paper Presented at the CODESRIA 30th Anniversary Celebrations Conference on 'Intellectuals, Nationalism and the Pan-African Ideal' held in Dakar, Senegal, October 2003.

Njubi, F. N., 2002, 'Migration, Identity and the Politics of African Intellectuals in the North', Paper presented during the 10th CODESRIA General Assembly, Kampala, Uganda, December 8-12, 2002.

Owusu, M., 1971, 'Viewpoint: Or Just New Stereotypes?', in Africa Report, Vol. 16, no. 7 .

Richburg, K. B., 1997, Out of America: A Black Man Confronts Africa, Basic Books.

Robinson, P. T., 2003, 'Area Studies in Search of Africa,' UCIAS Edited Volume 3, Article 6.

Robinson, P., 1997, 'Local/Global Linkages and the Future of African Studies', in Africa Today, Vol. 44, no. 2.

Russell, M. and Mugyenyi, M., 1997, 'Armchair Empiricism: A Reassessment of Data Collection in Survey Research in Africa', in African Sociological Review, Vol. 1, No. 1.

Sardar, Z. and Davis, M. W., 2002, Why Do People Hate America? Cambridge: Icon Press.

Skinner, E. P., 1983, 'Afro-Americans in Search of Africa: The Scholars' Dilemma', in Pearl T. Robinson and Elliot P. Skinner, eds., Transformation and Resiliency in Africa, Washington D. C.: Howard University Press.

Smock, A., 1970, 'A Critical Look at American Africanists', in Africa Report, Vol. 15 , no. 9.

Thornton, J., 1992, Africa and Africans in the Making of the Atlantic World, 1400-1680, New York: Cambridge University Press. 
Uchendu, V., 1977, 'Africa and the Africanist: The Challenge of a Terminal Colonial Order', in ISSUE: A Journal of Opinion, Vol. 7, no. 1.

Van Sertima, I., 1976, They Came Before Columbus, New York: Random House.

Veney, C. R. and Zeleza, P. T., 2001, 'Women's Scholarly Publishing in African Studies', in Cassandra Rachel Veney and Paul Tiyambe Zeleza, eds., Women in African Studies Scholarly Publishing, Trenton, NJ: Africa World Press.

Von Eschen, P. M., 1997, Race against Empire: Black Americans and AntiColonialism,1937-1957, Ithaca and London: Cornell University Press.

Wamba, P., 1999, Kinship: A Family Journey in Africa and America, New York: Plume.

Zeleza, P. T., 1997, Manufacturing Africa Studies and Crises, Dakar: CODESRIA.

Zeleza, P. T., 2003, Rethinking Africa's Globalization: Volume 1: The Intellectual Challenge, Trenton NJ: Africa World Press. 